Dikirim: 11 April 2017 Diterbitkan: 1 Juni 2017

\section{Kualitas udara hasil pembakaran avtur dan gangguan fungsi paru pekerja di bandara Supadio Pontianak}

\author{
Air quality of aviation building and disturbed lung function of \\ workers in Supadio Airport Pontianak
}

Zuzun Nazila ${ }^{1} \&$ Adi Heru Sutomo ${ }^{2}$

\begin{abstract}
Purpose: This study aimed to determine the relationship of air quality aviation fuel combustion products with impaired lung function in workers in Pontianak Supadio International Airport. Methods: This research was an observational study using a cross-sectional approach involving 60 people. Sampling technique used total sampling. The statistical analysis used Fisher exact and logistic regression tests, with significance level of $p<0.05$ and $95 \%$ confidence interval and odds ratios. Results: Based on bivariate analysis from 36 samples the results were: $\mathrm{NO}_{2}$ variable $(p=0.04), \mathrm{SO}_{2}(p=0.15)$, dust $(p=$ $0.25)$, age $(p=0.20)$, working period $(p=0.08)$, nutritional status $(p=0.09)$, and smoking habits $(p=0.03)$. Conclusion: There is significant correlation between the variables of $\mathrm{NO}_{2}$ and smoking habits with impaired lung function, while the variables: $\mathrm{SO}_{2}$, dust, age, working period and nutritional status had no significant correlation with lung function disorders.
\end{abstract}

Keywords: air quality; the burning aircraft fuel; impaired lung function

\footnotetext{
1 Departemen Perilaku Kesehatan, Lingkungan, dan Kedokteran Sosial, Fakultas Kedokteran, Universitas Gadjah Mada (Email:zuzun.nazila@gmail.com)

${ }^{2}$ Departemen Kedokteran Keluarga, Komunitas dan Bioetika, Fakultas Kedokteran, Universitas Gadjah Mada
} 


\section{PENDAHULUAN}

Frekuensi penerbangan di dalam negeri saat ini meningkat seiring pertambahan jumlah operasi maskapai penerbangan yang beroperasi baik domestik dan internasional. Kepadatan lalu lintas udara meningkat, hal tersebut tentu semakin meningkatkan penggunaan bahan bakar pesawat dan semakin meningkat pula polutan udara yang dilepaskan hasil dari pembakaran tersebut yang dikhawatirkan memiliki dampak merugikan terhadap kesehatan (1).

Konsentrasi polutan ambien di bandara berhubungan dengan aktivitas landing take off (LTO) pesawat (2). Penelitian ini fokus pada aktivitas pesawat udara pada fase LTO karena terkait dengan kualitas udara lokal di bandar udara mengingat ada jeda waktu yang cukup lama antara pesawat yang akan take off dari tempat parkir menuju landasan pacu dan pesawat yang landing dari landasan pacu menuju tempat parkir (3). Saat jeda waktu tersebut mesin pesawat dalam keadaan hidup dan terjadi pembakaran avtur pesawat sedangkan posisi pesawat masih berada di tempat parkir atau sekitar landasan pacu, dimana banyak pekerja ground handling yang berada di sekitar tempat tersebut yang setiap hari bekerja dengan tidak menggunakan alat pelindung diri (APD). Pekerja di bandara yang berisiko terpapar adalah baggage handlers, catering drivers, cleaning staff, airside security, landside security (4).

Dokumen aviation and emission a prime (2005) yang dikeluarkan Federal Aviation Administration (FAA) menyatakan mesin pesawat terbang menghasilkan emisi gas buang yang dapat berpotensi mencemari udara, seperti nitrogen oksida $\left(\mathrm{NO}_{\mathrm{x}}\right)$, sulfur oksida $\left(\mathrm{SO}_{\mathrm{x}}\right)$, karbon dioksida $\left(\mathrm{CO}_{2}\right)$, uap air $\left(\mathrm{H}_{2} \mathrm{O}\right)$, karbon monoksida (CO) (5). Mesin pesawat terbang akan menghasilkan emisi yang dilepaskan ke udara meliputi $\mathrm{CO}, \mathrm{CO}_{2}, \mathrm{H}_{2} \mathrm{O}, \mathrm{SO}_{2}, \mathrm{NO}_{2}$, $\mathrm{HC}(6)$.

Organ pernapasan merupakan bagian pertama yang berhubungan dengan berbagai bahan pencemar udara yang dapat berpengaruh terhadap sistem organ (7). Beberapa polutan di udara yang dapat menyebabkan gangguan pernapasan adalah $\mathrm{SO}_{2}, \mathrm{NO}_{2}$, dan partikel debu. Polutan ini dapat mengiritasi saluran pernapasan, menyebabkan gangguan fungsi paru dan masalah pernapasan (8).

Bandar udara internasional Supadio Pontianak yang dikelola oleh PT. Angkasa Pura II merupakan bandar udara yang mempunyai tingkat kesibukan cukup tinggi, dengan rata-rata jumlah pesawat terbang yang beroperasi sekitar 40 pesawat per hari. Peningkatan frekuensi penerbangan menimbulkan masalah polusi udara lokal yang berpengaruh terhadap orang yang tinggal di sekitar bandara. Risiko terbesar kemungkinan dialami pekerja yang mendapat paparan secara terus menerus. Emisi pesawat adalah salah satu faktor yang diduga menyebabkan gangguan kesehatan terutama pada saluran pernapasan (1).

Selain faktor pekerjaan, fungsi paru dapat dipengaruhi oleh usia, jenis kelamin, ukuran paru, kelompok etnik, kebiasaan merokok, kebiasaan latihan (9). Selain itu gangguan fungsi paru dipengaruhi oleh beberapa faktor, antara lain umur, jenis kelamin, status gizi, riwayat penyakit, kebiasaan merokok, masa kerja dan penggunaan alat pelindung diri (10).

Penelitian mengenai polusi udara yang bersumber dari transportasi udara belum banyak diketahui, apalagi jika dikaitkan dengan kesehatan pekerja di sekitar tempat terpaparnya polusi. Oleh karena itu, penelitian ini penting untuk dilakukan. Penelitian ini dilakukan dengan tujuan untuk mengetahui hubungan kualitas udara hasil pembakaran avtur dengan gangguan fungsi paru pada pekerja di bandara internasional Supadio Pontianak.

\section{METODE}

Penelitian ini merupakan penelitian observasional analitik dengan desain cross sectional. Studi cross sectional merupakan studi yang dilakukan dengan menelaah sebab akibat pada waktu yang bersamaan (11). Besar sampel penelitian sebanyak 36 orang yang bekerja sebagai ground handling di bandara internasional Supadio Pontianak. Kriteria eksklusi meliputi mempunyai riwayat penyakit paru, sedang sakit infeksi saluran pernapasan akut (ISPA), merokok berat, dan tidak berada di lokasi penelitian ketika penelitian dilaksanakan. Penelitian ini dilaksanakan pada bulan Februari 2017.

Variabel bebas adalah kualitas udara yang diukur dari paparan $\mathrm{SO}_{2}$ dan $\mathrm{NO}_{2}$, variabel terikat yaitu gangguan fungsi paru, variabel pengganggu yaitu umur, masa kerja, status gizi, kebiasaan merokok dan debu. Instrumen dalam penelitian ini menggunakan air sampler impinger merk inscien pro US-1012 untuk mengukur kualitas udara (paparan $\mathrm{SO}_{2}, \mathrm{NO}_{2}$ ), sensidyne 80570 nephelometer untuk mengukur kadar debu, spirometer dengan merk spiro analyzer ST-75 untuk mengukur kapasitas paru, timbangan berat badan merk omron HN 383 untuk mengetahui berat badan, meteran tinggi badan merk ZT 120 untuk mengetahui tinggi badan, dan lembar isian data untuk memperoleh informasi tambahan yang meliputi umur, 
masa kerja, kebiasaan merokok, riwayat penyakit, dan riwayat pekerjaan.

Analisis data dilakukan dengan analisis univariat, analisis bivariat dengan uji statistik menggunakan chi square dan fisher, serta analisis multivariat menggunakan uji regresi logistik. Keseluruhan tes menggunakan odd ratio (OR), dengan confidence interval (CI) 95\% dan tingkat kemaknaan p 0,05 (12,13). Penelitian ini telah mendapat persetujuan dari komite etik FK UGM.

\section{HASIL}

Tabel 1 menunjukkan bahwa hasil pengukuran kualitas udara yang dilakukan di sekitar landasan apron yaitu pada titik A dengan titik koordinat $00^{\circ} 08^{\prime} 4921^{\prime}$ 'S $-109^{\circ} 24$ '1403 ' 'E, titik B dengan titik koordinat $00^{\circ} 08^{\prime} 5103$ ”'S $109^{\circ} 241489$ “ 'E dan titik C dengan titik koordinat $00^{\circ} 08^{\prime} 4321$ ، 'S $109^{\circ} 24$ '1403 ، 'E tidak terdapat hasil yang melebihi ambang batas baku mutu udara ambien menurut PP Nomor 41 Tahun 1999.

Tabel 1. Hasil pengukuran kualitas udara

\begin{tabular}{lllllll}
\hline \multirow{2}{*}{ Parameter Satuan } & \multirow{2}{*}{$\begin{array}{c}\text { Baku } \\
\text { Mutu }\end{array}$} & \multicolumn{2}{l}{$\begin{array}{l}\text { Hasil Pengukuran } \\
\text { Kualitas Udara }\end{array}$} & \multirow{2}{*}{ Rerata } \\
\cline { 3 - 6 } & & \multicolumn{2}{l}{ Titik A } & Titik B & Titik C & \\
\hline $\mathrm{SO}_{2}$ & $\mu \mathrm{g} / \mathrm{Nm}^{3}$ & $900^{*}$ & 301,90 & 310,41 & 281,07 & 281,07 \\
$\mathrm{NO}_{2}$ & $\mu \mathrm{g} / \mathrm{Nm}^{3}$ & $400^{*}$ & 170,34 & 181,11 & 169,14 & 169,14 \\
$\mathrm{Debu}$ & $\mu \mathrm{g} / \mathrm{Nm}^{3}$ & $90^{*}$ & 33,96 & 34,55 & 28,37 & 28,37 \\
\hline
\end{tabular}

Paparan $\mathrm{SO}_{2}, \mathrm{NO}_{2}$ dan debu paling banyak terdapat pada titik B. Hal ini disebabkan karena titik B merupakan tempat yang dekat dengan lalu lintas pesawat yang masuk dan keluar dari landasan pacu.

Tabel 2 menunjukkan bahwa paparan $\mathrm{SO}_{2}$ dengan gangguan fungsi paru menunjukkan hubungan yang tidak bermakna dengan nilai p 0,15 ( p > 0,05). Artinya secara statistik tidak terdapat hubungan antara $\mathrm{SO}_{2}$ dengan gangguan fungsi paru pekerja. Hasil perhitungan OR antara variabel $\mathrm{SO}_{2}$ dengan gangguan fungsi paru didapatkan 1.1. Artinya secara klinis $\mathrm{SO}_{2}$ tidak berpeluang menimbulkan gangguan fungsi paru karena nilai OR < 1,5 yaitu 1,1.

Tabel 2 juga menjelaskan terdapat hubungan bermakna antara paparan $\mathrm{NO}_{2}$ dengan gangguan fungsi paru dengan nilai p 0,04 ( $<<0,05)$. Hasil perhitungan $\mathrm{OR}$ antara variabel $\mathrm{NO}_{2}$ dengan gangguan fungsi paru menunjukkan nilai 1,2. Artinya secara klinis $\mathrm{NO}_{2}$ tidak berpeluang menimbulkan gangguan fungsi paru karena nilai OR < 1,5 yaitu 1,2.

Tabel 2 menunjukkan secara statistik tidak terdapat hubungan yang bermakna antara paparan debu dengan gangguan fungsi paru dengan nilai $\mathrm{p}$ 0,25.
Sedangkan OR antara variabel debu dengan gangguan fungsi paru menunjukkan nilai 1,3. Artinya secara klinis debu tidak berpeluang menimbulkan gangguan fungsi paru karena nilai OR < 1,5 yaitu 1,3.

Tabel 2 menunjukkan secara statistik tidak terdapat hubungan yang bermakna antara variabel umur dengan gangguan fungsi paru dengan nilai p 0,20. Secara klinis berdasarkan perhitungan OR menunjukkan bahwa pekerja yang berusia > 30 tahun memiliki peluang 5,6 kali lebih besar mengalami gangguan fungsi paru dibandingkan dengan pekerja yang berusia $\leq 30$ tahun.

Tabel 2. Odds ratio variabel penelitian

\begin{tabular}{|c|c|c|c|c|}
\hline \multirow{3}{*}{ Variabel } & \multicolumn{2}{|c|}{ Gangguan Fungsi Paru } & \multirow{3}{*}{ OR } & \multirow{3}{*}{ CI 95\% } \\
\hline & Ya & Tidak & & \\
\hline & $\%$ & $\%$ & & \\
\hline $\mathrm{SO}_{2}$ & 19,4 & 80,6 & 1,1 & $0,97-1,17$ \\
\hline $\mathrm{NO}_{2}$ & 19,4 & 80,6 & 1,2 & $1,00-1,39 *$ \\
\hline Debu & 19,4 & 80,6 & 1,3 & $0,84-1,89$ \\
\hline \multicolumn{5}{|l|}{ Umur } \\
\hline 30 tahun & 28,6 & 71,4 & 5,6 & $0,54-275,59$ \\
\hline$\leq 30$ tahun & 6,7 & 93,3 & & \\
\hline \multicolumn{5}{|l|}{ Masa Kerja } \\
\hline 10 tahun & 35,7 & 64,3 & 5,6 & $0,70-65,68$ \\
\hline$\leq 10$ tahun & 9,1 & 90,9 & & \\
\hline \multicolumn{5}{|l|}{ Status Gizi } \\
\hline Tidak normal & 31,6 & 68,4 & 7,4 & $0,71-360,38$ \\
\hline Normal & 5,9 & 94,1 & & \\
\hline \multicolumn{5}{|l|}{ Merokok } \\
\hline Merokok sedang & 41,7 & 58,3 & 3 & $0,69-13,89$ \\
\hline Merokok ringan & 18,2 & 81,8 & 1,8 & $0,39-8,78$ \\
\hline Tidak merokok & 0 & 100 & & \\
\hline
\end{tabular}

Tabel 2 menjelaskan nilai p 0,08 (p > 0,05) yang berarti secara statistik tidak terdapat hubungan yang bermakna antara masa kerja dengan gangguan fungsi paru. Sedangkan secara klinis berdasarkan perhitungan OR menunjukkan bahwa pekerja dengan masa kerja > 10 tahun memiliki peluang 5,6 kali lebih besar mengalami gangguan fungsi paru dibandingkan dengan pekerja dengan masa kerja $\leq 10$ tahun.

Tabel 3 Model regresi logistik

\begin{tabular}{|c|c|c|c|c|c|}
\hline Variabel & OR & SE & $\mathbf{Z}$ & $\mathbf{p}$ & $95 \%$ CI \\
\hline $\mathrm{NO}_{2}$ & 1,529 & 0,381 & 1,70 & 0,089 & 0,937924-2,495697 \\
\hline $\mathrm{SO}_{2}$ & 0,901 & 0,092 & $-1,02$ & 0,308 & 0,737333-1,101104 \\
\hline Umur & 103,3 & 254,3 & 1,88 & 0,059 & $0,831526-12851,87$ \\
\hline Masa & 0,088 & 0,186 & -1.15 & 0,249 & $0,001448-5,443808$ \\
\hline Kerja & 14,64 & 21,39 & 1,84 & 0,066 & $0,836566-256,4489$ \\
\hline \multicolumn{6}{|c|}{ Status Gizi } \\
\hline $\begin{array}{l}\text { N } \\
\text { Prob chi }{ }^{2} \\
\text { Pseudo } \mathbf{R}^{2}\end{array}$ & $\begin{array}{l}36 \\
0,0185 \\
0,3827\end{array}$ & & & & \\
\hline
\end{tabular}

Tabel 3 menunjukkan analisis regresi logistik. Penelitian ini menemukan hubungan signifikan secara bersama-sama antara variabel $\mathrm{NO}_{2}, \mathrm{SO}_{2}$, umur, masa kerja dan status gizi dengan gangguan fungsi paru 
dengan p 0,0185. Namun jika dilihat dari masing masing variabel tidak terdapat hubungan yang signifikan dengan gangguan fungsi paru $\left(\mathrm{NO}_{2} \mathrm{p} \mathrm{0,089}\right.$, $\mathrm{SO}_{2}$ p 0,308, Umur p 0,059, masa kerja p 0,249 dan status gizi p 0,066). Ketika keberadaan faktor itu secara bersama-sama maka variabel $\mathrm{NO}_{2}, \mathrm{SO}_{2}$, umur, masa kerja dan status gizi berkontribusi terhadap gangguan fungsi paru sebesar 38\% dan sebesar 62\% dipengaruhi oleh variabel lain yang tidak diteliti.

\section{BAHASAN}

Polutan udara yang dihasilkan pesawat terbang dan kendaraan bermotor adalah pada kadar polutan yang dihasilkan (14). Mesin pesawat terbang akan menghasilkan emisi yang dilepaskan ke udara meliputi $\mathrm{CO}$, $\mathrm{CO}_{2}, \mathrm{H}_{2} \mathrm{O}, \mathrm{SO}_{2}, \mathrm{NO}_{2}, \mathrm{HC}$ (6). Pencemaran udara menimbulkan dampak buruk bagi kesehatan manusia, penyakit yang timbul antara lain infeksi saluran pernafasan atas, gangguan fungsi paru, hipertensi, jantung, kanker dan lain sebagainya (15). Polutan di udara yang dapat mengiritasi saluran pernapasan dan gangguan fungsi paru adalah $\mathrm{SO}_{2}, \mathrm{NO}_{2}$ dan debu (8).

Uji statistik menunjukkan tidak terdapat hubungan yang bermakna antara paparan $\mathrm{SO}_{2}$ dengan gangguan fungsi paru (p 0,15). Hasil ini sejalan dengan penelitian Husaini bahwa tidak ada hubungan yang bermakna antara pajanan $\mathrm{SO}_{2}$ dengan gangguan fungsi paru restriktif (16). Hal tersebut diperkuat oleh Damri bahwa paparan $\mathrm{SO}_{2}$ tidak ada hubungan yang signifikan terhadap kejadian penyakit pekerja parkir mall dengan nilai p 0,122 (17).

Hasil penelitian menyatakan tidak ada hubungan yang bermakna antara paparan $\mathrm{SO}_{2}$ dengan gangguan fungsi paru, karena paparan $\mathrm{SO}_{2}$ yang diperoleh tidak melebihi nilai ambang batas (NAB) dan masa kerja pegawai yang kurang dari 10 tahun sehingga efek dari paparan $\mathrm{SO}_{2}$ yang terhirup saat bekerja belum tampak.

Secara statistik terdapat hubungan yang bermakna antara paparan $\mathrm{NO}_{2}$ dengan gangguan fungsi paru dengan $p$ 0,04 $(<0,05)$. Hasil ini sejalan dengan penelitian Wulansari bahwa terdapat hubungan yang bermakna antara paparan $\mathrm{NO}_{2}$ dengan gangguan fungsi paru (18). Hal ini diperkuat dengan penelitian Tunnicliffe bahwa ada hubungan antara paparan emisi bahan bakar pesawat dengan gejala gangguan pernapasan pada pekerja di bandara (19).

Paparan emisi bahan bakar pesawat berhubungan dengan gejala gangguan pernapasan pekerja di bandara (1). Hal ini disebabkan karena paparan $\mathrm{NO}_{2}$ di lingkungan kerja akan masuk ke dalam tubuh saat kita bernapas, jika hal tersebut terjadi secara terus menerus maka akan mengakibatkan gangguan fungsi paru. Hal ini diperkuat oleh penelitian Ionel, dkk. bahwa jumlah paparan $\mathrm{NO}_{2}$ yang berbanding lurus dengan kepadatan lalu lintas pesawat di bandara Romania (20). Paparan polusi di bandara berhubungan dengan peningkatan risiko terhadap penyakit pernapasan dan kardiovaskuler (21).

Selain paparan di lingkungan kerja kapasitas paru dipengaruhi oleh anatomi tubuh, jenis kelamin, merokok, riwayat penyakit, pencemaran udara dan aktivitas fisik (22). Gangguan fungsi paru juga dipengaruhi oleh beberapa faktor, antara lain umur, jenis kelamin, riwayat penyakit, status gizi, kebiasaan merokok, masa kerja dan penggunaan alat pelindung diri (23).

Secara klinis pekerja yang berumur lebih dari 30 tahun berisiko 5,6 kali memiliki gangguan fungsi paru dibanding pekerja yang berusia kurang dari 30 tahun, namun uji statistik menunjukkan umur tidak memiliki hubungan yang bermakna dengan gangguan fungsi paru (p 0,20). Hasil ini sejalan dengan penelitian Wulandari, dkk, Zarandi, dkk dan Anes, dkk yang menyatakan tidak ada hubungan signifikan antara umur dengan gangguan fungsi paru (24-26).

Perubahan usia berpengaruh terhadap perubahan organ tubuh. Fungsi faal paru meningkat pada usia 22-30 tahun, dan menurun secara perlahan sesuai perubahan usia (22,27). Umur merupakan variabel penting dalam gangguan fungsi paru. Semakin bertambah umur disertai kondisi lingkungan buruk, maka kemungkinan terkena suatu penyakit penurunan fungsi paru menjadi lebih besar. Secara statistik umur tidak memengaruhi kapasitas paru pekerja. Hal ini bisa disebabkan karena pola hidup yang sehat dan status gizi yang baik, bisa juga dipengaruhi faktor lain seperti jenis kelamin, berat badan, tinggi badan dan kebiasaan olah raga (28).

Hasil uji statistik menunjukkan tidak ada hubungan yang bermakna antara masa kerja dengan gangguan fungsi paru. Hasil ini sejalan dengan penelitian Draid, dkk dan Rahmansyah yang menyatakan bahwa masa kerja dengan gangguan fungsi paru tidak memiliki hubungan bermakna $(29,30)$. Variabel yang berpotensi menyebabkan gangguan fungsi paru adalah lamanya seseorang terpapar polutan, artinya semakin lama masa kerja seseorang, maka semakin lama pula waktu paparan terhadap polutan tersebut (27).

Status gizi tidak menunjukkan hubungan yang bermakna dengan gangguan fungsi paru (p 0,09). Hasil ini sejalan dengan penelitian Widjanarti dan Pratiwi bahwa status gizi dengan gangguan fungsi paru tidak memiliki hubungan bermakna $(31,32)$. 
Pekerja dengan status gizi baik, produktivitas kerja akan baik pula, karena status gizi memengaruhi daya tahan dan kemampuan kerja. Kekurangan gizi menyebabkan kemampuan detoksifikasi tubuh terhadap benda asing menurun karena penurunan sistem imunitas dan antibodi sehingga orang menjadi lebih mudah sakit (33). Kekurangan status gizi menyebabkan organ tubuh tidak berkembang dan berfungsi dengan baik, sedangkan kelebihan status gizi menyebabkan penumpukan lemak berlebih yang dapat mengganggu proses kerja organ dalam tubuh (34). Selain status gizi faktor lain yang memengaruhi kondisi kesehatan adalah kebiasaan merokok, tekanan darah, aktivitas fisik dan riwayat genetik (30). Seorang perokok membutuhkan asupan nutrisi yang mengandung antioksidan tinggi, karena rokok dapat menimbulkan kerusakan organ pernapasan (35). Kebiasaan merokok menyebabkan gangguan ventilasi paru, karena menyebabkan iritasi dan produksi sekresi berlebih pada bronkus (36).

Penelitian ini tidak menemukan hubungan bermakna antara kebiasaan merokok dengan gangguan fungsi paru. Hasil ini sejalan dengan penelitian Indira dan Kumendong bahwa tidak ada hubungan antara merokok dengan gangguan fungsi paru $(37,38)$. Hasil penelitian tidak sesuai dengan teori yang ada karena asupan nutrisi yang baik dan aktivitas fisik yang tinggi menunjang daya tahan tubuh dan meningkatkan kapasitas paru.

Hasil uji statistik menunjukkan tidak ada hubungan yang bermakna antara paparan debu dengan gangguan fungsi paru. Hasil ini sejalan dengan penelitian Sunuh yang menyatakan tidak ada hubungan yang bermakna antara paparan debu dengan gangguan fungsi paru (33). Hal ini diperkuat penelitian Widjanarti bahwa tidak terdapat hubungan yang bermakna antara paparan debu dengan kapasitas paru pekerja (31). Paparan debu yang terhirup oleh pekerja berkaitan dengan efek kesehatan baik akut maupun kronis terutama pada sistem pernapasan dan kinerja fungsi paru $(39,40)$. Hal ini sejalan dengan yang dilakukan Masngut, dkk yang menjelaskan hubungan efek paparan debu terhadap kesehatan termasuk gejala pernapasan dan perubahan fungsi paru (41).

Hasil penelitian menyatakan bahwa tidak ada hubungan yang bermakna antara paparan debu dengan gangguan fungsi paru, karena paparan debu yang diperoleh tidak melebihi NAB dan masa kerja pegawai yang kurang dari 10 tahun sehingga efek dari paparan debu yang terhirup saat bekerja belum tampak.

\section{SIMPULAN}

Penelitian menyimpulkan bahwa secara statistik terdapat hubungan yang signifikan antara paparan $\mathrm{NO}_{2}$ dengan gangguan fungsi paru. Sedangkan faktor lain yang tidak berhubungan dengan gangguan fungsi paru adalah $\mathrm{SO}_{2}$, debu, umur, masa kerja, status gizi, kebiasaan merokok, karena responden rata-rata masih berusia 30 tahun dengan status gizi yang baik serta masa kerja yang kurang dari 10 tahun.

Adapun saran yang dapat diberikan bagi PT. Angkasa Pura II Pontianak adalah agar memberikan pembinaan tentang Keselamatan dan Kesehatan Kerja (K3) kepada para pekerja, melakukan pemeriksaan kesehatan secara berkala termasuk pemeriksaan fungsi paru, menyediakan alat pelindung diri (APD) bagi pekerja. Bagi peneliti lain agar melakukan penellitian lebih lanjut dengan dengan penambahan jumlah sampel dan variabel yang berbeda untuk mengetahui faktor lain yang berhubungan dengan terjadinya gangguan fungsi paru.

\section{Abstrak}

Tujuan: Penelitian bertujuan mengetahui hubungan produk bahan bakar avtur dengan kualitas udara dengan gangguan fungsi paru pada pekerja di bandara Supadio Pontianak. Metode: Penelitian observasional menggunakan pendekatan cross sectional. Teknik sampling menggunakan total sampling dengan populasi 60 orang. Uji statistik menggunakan regresi fisher exact dan logistik. Uji keseluruhan menggunakan tingkat signifikansi $\mathrm{p}$ 0,05 dengan interval kepercayaan 95\% dan rasio odds. Hasil: Berdasarkan analisis bivariat dari 36 sampel yang dilakukan, variabel $\mathrm{NO}_{2}(\mathrm{p} 0,04), \mathrm{SO}_{2}(\mathrm{p}$ $0,15)$, debu (p 0,25), umur (p 0,20), periode kerja ( $p$ 0,08), status gizi (p 0,09), kebiasaan merokok (p 0,03).

Simpulan: Secara statistik terdapat hubungan yang signifikan antara variabel $\mathrm{NO}_{2}$ dan kebiasaan merokok dengan gangguan fungsi paru, sedangkan variabel $\mathrm{SO}_{2}$, debu, umur, masa kerja dan status gizi tidak memiliki hubungan yang signifikan dengan kelainan fungsi paru.

Kata kunci: kualitas udara; bahan bakar pesawat terbakar; gangguan fungsi paru 


\section{PUSTAKA}

1. Touri, L., Marchetti, H., Sari-Minodier, I., Molinari, N. and Chanez, P., The airport atmospheric environment: respiratory health at work. European respiratory review 2013; 22(128), pp.124-130.

2. Hsu, H.H., Adamkiewicz, G., Houseman, E.A., Vallarino, J., Melly, S.J., Wayson, R.L., Spengler, J.D. and Levy, J.I. The relationship between aviation activities and ultrafine particulate matter concentrations near a mid-sized airport. Atmospheric Environment 2012;50, pp.328-337.

3. Yim, S.H., Stettler, M.E., and Barrett, S.R. Air quality and public health impacts of UK airports. Part II: Impacts and policy assessment.Atmospheric Environment 2013;67, pp.184-192.

4. Moller, K.L., Thygesen, L.C., Schipperijn, J., Loft, S., Bonde, J.P., Mikkelsen, S. and Brauer, C. Occupational Exposure to Ultrafine Particles among Airport Employees-Combining Personal Monitoring and Global Positioning System. PloS one 2014;9(9), p.e106671.

5. Kaleka, Y. U., Budiarsa Suyasa, I. W. \& Mahendra, M. Beban Emisi Aktivitas LTO (Landing Take Off) Pesawat Udara Di Bandar Udara Internasional I Gusti Ngurah Rai Bali, Ecotrophic: Journal of Environmental Science 2015;9(1), 72-79.

6. Stettler, M.E.J., Eastham, S. and Barrett, S.R.H. Air quality and public health impacts of UK airports. Part I: Emissions. Atmospheric environment 2011;45(31), pp.5415-5424.

7. Loscalzo, J. Harrison's Pulmonary and Critical Care Medicine, Mc Graw Hill Companeis, United States;2010.

8. Sandra, C. Pengaruh penurunan kualitas udara terhadap fungsi paru dan keluhan pernafasan pada polisi lalu lintas polwiltabes Surabaya.IKESMA 2013;9(1), Jakarta.

9. Harrington, J.M., \& Gill, F.S. Buku Saku Kesehatan Kerja, Edisi 3, Buku Kedokteran, EGC, Jakarta; 2005.

10. Fathurrahman. C., Jayanti. S., \& Ekawati. Faktor-Faktor yang Berhubungan dengan Gangguan Fungsi Paru pada Pekerja yang Terpapar Potassium Permanganate dan Phosphoric Acid di Industri Garmen. Universitas Diponegoro, Semarang; 2014.

11. Swarjana, I.K. Metodologi Penelitian Kesehatan (Edisi Revisi) Penerbit ANDI, Yogyakarta; 2015.

12. Dahlan, M.S. Mendiagnosis dan Menata Laksana 13 Penyakit Statistik.CV Sagung Seto. Jakarta; 2010.

13. Dahlan, M.S. Analisis Multivariant Regresi Logistik, Epidemiologi Indonesia, CV Sagung Seto. Jakarta; 2012.

14. Slamet, S. Potensi Dan Dampak Polusi Udara Dari Sektor Penerbangan, Berita Dirgantara, 7(2); 2010.

15. Sugiarti. "Gas Pencemar Udara Dan Pengaruhnya Bagi Kesehatan Manusia Air Pollutan Gasses and The Influence of Human Healt." Jurnal Chemica Vol. 10 Nomor 1 Juni 2009; 50-58.

16. Husaini. 'Hubungan Pajanan $\mathrm{CO}, \mathrm{SO}_{2}, \mathrm{NO}_{2}$, Uap Besi dan Debu Besi Dengan Gangguan Fungsi Paru Dan Kadar Imunoglobulin Serum Perajin Logam', Disertasi, Universitas Gadjah Mada, Yogyakarta; 2014.

17. Damri., Ilza, M., Afandi, D. Analisis Paparan Co Dan So2 Pada Petugas Parkir di Basement Mall Ska di Kota Pekanbaru. Dinamika Lingkungan 2016;3(1), pp.42-47.

18. Wulansari, A. 'Faktor-Faktor Yang Berhubungan Dengan Fungsi Paru Anak Sekolah Dasar di Lingkungan Lalu Lintas Padat dan Tidak Padat Yogyakarta', Tesis, Universitas Gadjah Mada, Yogyakarta; 2015.

19. Tunnicliffe, W.S., O'Hickey, S.P., Fletcher, T.J., Miles, J.F., Burge, P.S. and Ayres, J.G. Pulmonary function and respiratory symptoms in a population of airport workers. Occupational and environmental medicine 1999;56(2), pp.118-123.

20. Ionel, I., Nicolae, D., Popescu, F., Talianu, C., Belegante, L., and Apostol, G. Measuring air pollutants in an international Romania airport with point and open path instruments. Romanian Journal of Physics 2011;56(3-4), pp.507-519.

21. Burdzik, A. and Kew, G. Health Impact Assessment: Cape Town International Airport Runway Re-alignment and Associated Infrastructure Project; 2015.

22. Guyton, A.C. Fisiologi Manusia dan Mekanisme Penyakit, Buku Kedokteran ECG, Jakarta;1995

23. Fathurrahman. C., Jayanti. S., \& Ekawati. Faktor-Faktor yang Berhubungan dengan Gangguan Fungsi Paru pada Pekerja yang Terpapar Potassium Permanganate dan Phosphoric Acid di Industri Garmen. Universitas Diponegoro, Semarang; 2014.

24. Wulandari, D.R., Hadisaputro. S., \& Suhartono. Berbagai Faktor yang Berhubungan dengan Kejadian Gangguan Fungsi Paru dalam Ruang Kerja (Studi Kasus Pekerja Industri Rumahan Electroplating di Kecamatan Talang Kabupaten Tegal). Jurnal Kesehatan Lingkungan Indonesia 2013;12 (1), 94-98.

25. Anes, N.I., Umboh, J.M.L., Kawatu, P.A.T. Faktor-Faktor yang Berhubungan dengan Gangguan Fungsi Paru pada Pekerja di PT. Tonasa.

26. Rahmansyah, S.T. 'Pengaruh Kadar Debu Silika dan Kepatuhan Pekerja Menggunakan Alat Pelindung Diri Terhadap Kapasitas Paru Bagian Produksi Semen di PT X Sulawesi Selatan', Tesis, Universitas Gadjah Mada, Yogyakarta; 2016.

27. Widjanarti, M.P. 'Hubungan Antara Kadar Debu Respirabel dengan Parameter Uji Fungsi Paru pada Pekerja Powder Coating PT X Surakarta', Tesis, Universitas Gadjah Mada, Yogyakarta; 2015.

28. Pratiwi, A. D. 'Masa Kerja, Status Gizi, Tempat Kerja, Fungsi Paru dan Kelelahan Kerja Pada Pekerja di Stasiun Gilingan Pabrik Gula Madukismo PT Madubaru', Tesis, Universitas Gadjah Mada, Yogyakarta; 2010.

29. Sunuh, H. S. 'Hubungan Kualitas Udara Ruang Perawatan Dengan Gangguan Fungsi Paru Perawat di RSUD Undata Palu SULTENG', Tesis, Universitas Gadjah Mada, Yogyakarta; 2011.

30. Kandung, R.P. Hubungan Antara Karakterisrik Pekerja dan Pemakaian Alat Pelindung Pernafasan (Masker) dengan Kapasitas Fungsi Paru pada Pekerja Wanita Bagian Pengampelasan di Industri Mebel "X" Wonogiri, Jurnal Kesehatan Masyarakat 2013;2(1)

31. Gibney, M.J., Margetts, B.M., Kearney, J.M., Arab, L. Gizi Kesehatan Masyarakat (Public Health Nutrition), Buku Kedokteran EGC, Jakarta;2005.

32. Yusitriani., Russeng, S.S., \& Muis, M. Faktor Yang Berhubungan Dengan Kapasitas Paru Pekerja Paving Block CV Sumber Galian, Artikel, Universitas Hasanuddin, Makasar; 2014. 
33. Indira, R.A.L. 'Paparan Debu Terhirup Terhadap Hasil Tes Fungsi Paru Pada Pekerja Sentra Perajin Pisau "Rukun Karya Lestasi” di Kabupaten Bantul', Tesis, Universitas Gadjah Mada, Yogyakarta; 2015.

34. Kumendong, D.J., Rattu, J.A. and Kawatu, P.A. Hubungan Antara Lama Paparan dengan Kapasitas Paru Tenaga Kerja Industri Mebel di CV. Sinar Mandiri Kota Bitung. KESMAS 2012;1(1), pp.5-10. 39.

35. Attarchi, M., Dehghan, F., Afrasyabi, M., Sadeghi, Z., \& Mohammadi, S. Combined Effect of Cigarette Smoking and Occupational Exposures on Lung Function : A Cross-sectional Study; 2013.

36. Yanagi, N., Kitamura, H., Mizuno, M., Hata, K.,Uchiyama, T., Kuga, H., \& Higashi, T. A 4-Year Follow-up Cohort Study of Respiratory Function in Toner-handling Workers. Safety and Health at Work; 2014 5(4), pp. 222-226.

37. Masngut, M.I., Baharudin, M.R., \& Rahman, A.A. A Systematic Review On Risk Factor For Reduce Lung Function Due To Occupational Respirable Dust Exposure 2005-2015. International Journal of Public Health and Clinical Sciences 2015;2(4), pp. 44-62. 
Berita Kedokteran Masyarakat, Volume 33 No. 6 Tahun 2017 